九州大学学術情報リポジトリ

Kyushu University Institutional Repository

\title{
Assessment of Surface and Groundwater Quality in Pig-raising Villages of Haiduong Province in Vietnam
}

Ho, Thi Lam Tra

Faculty of Natural Resources and Environment, Hanoi University of Agriculture

Cao, Truong Son

Faculty of Natural Resources and Environment, Hanoi University of Agriculture

Tran, Thi Loan

Department of Science and Technology, Haiduong province, Vietnam

Kurosawa, Kiyoshi

Institute of Tropical Agriculture, Kyushu University

他

https://doi.org/10.5109/17813

出版情報: 九州大学大学院農学研究院紀要. 55 (1)，pp.123-130，2010-02-26. Faculty of Agriculture, Kyushu University

バージョン :

権利関係 : 


\title{
Assessment of Surface and Groundwater Quality in Pig-raising Villages of Haiduong Province in Vietnam
}

\author{
Thi Lam Tra HO ${ }^{1}$, Truong Son $\mathrm{CAO}^{1}$, Thi Loan TRAN ${ }^{2}$, Kiyoshi KUROSAWA* \\ and Kazuhiko EGASHIRA ${ }^{3}$
}

\author{
Institute of Tropical Agriculture, Kyushu University, Fukuoka, 812-8581, Japan
}

(Received October 30, 2009 and accepted November 19, 2009)

\begin{abstract}
Surface and groundwater quality on inorganic nitrogen $(N)$ was monitored in the farming villages of Laivu commune, Kimthanh district, Haiduong province of northern Vietnam. In these villages, pig raising in the farm households has been enhanced since 2001, and the households feeding 10 to 150 pigs in a year amounted to $28.6 \%$ of total households of the commune. Monitoring was done at five times of a two-month interval during August 2007 and April 2008. The ammonium-N concentration was always higher than the nitrate-N concentration and showed temporal and spatial variations in both surface and groundwater. The temporal variation was rather wavy and the steady increase with time was not recognized. The spatial variation was ascribed to the difference in the intensification of pig raising among the villages. Both surface and groundwater were found to be seriously contaminated with ammonium-N in Laivu commune. The ammonium-N concentration was remarkably higher than the Vietnamese water standards for drinking purpose. Waste water and solid discharged directly from piggeries without any prevention treatment was identified as a source of $\mathrm{N}$ contaminating surface and groundwater. Attention should be paid to the alarmingly high level of ammonium-N in the surface and groundwater in the intensively livestock-raising as well as farming villages of the Red River Delta.
\end{abstract}

\section{INTRODUCTION}

Pollution of surface water by ammonium in the main rivers of the Red River Delta (RRD) was reported by World Bank (2003). Intensive farming of rice and vegetables accompanied by application of a lot of chemical fertilizers and intensive feeding of livestock and poultry with direct discharge of waste water and solid have spread over the RRD in northern Vietnam after issue of Doi Moi (renovation) in 1986. As a result, it has become evident that groundwater was severely contaminated with ammonium-nitrogen $(\mathrm{N})$ in the farming villages of the RRD where triple cropping of two rice and one winter vegetable in a year has been practiced (Kurosawa et al., 2006, 2008). However, research focused on the pollution of surface and groundwater caused by the intensive feeding of livestock and poultry in the RRD has not been conducted so far.

Laivu commune, located in Kimthanh district, Haiduong province in northern Vietnam, was selected for a case-study on the influence of intensive feeding of livestock on the water quality of environment. Laivu commune is an agro-based commune and rice had been mainly cultivated to support the life of local people until 2001. In addition to the rice cultivation, the farm household supplementarily fed one to several head of pig annually by agricultural residues without any effect on environment. In 2001, the industrial developing pol-

1 Faculty of Natural Resources and Environment, Hanoi University of Agriculture, Hanoi, Vietnam

2 Department of Science and Technology, Haiduong province, Vietnam

Emeritus Professor, Kyushu University

* Corresponding author (E-mail: kurosawa@agr.kyushu-u.ac.jp) icy of Haiduong province was issued and about 2/3 of total cultivated land of Laivu commune was expropriated from farmers for construction of the industrial zone. Since then, farmers were obliged to shift the fundamental agricultural production system from rice cultivation to pig raising, and pig raising in Laivu commune was enhanced to the annual feeding level of 150 head of pigs at maximum in a household. Rapid enhancement of pig raising in Laivu commune might have caused pollution of environment, especially surface and groundwater.

Monitoring of inorganic $\mathrm{N}$ in surface and groundwater was conducted in Laivu commune at five times of a two-month interval from August 2007 up to April 2008. Based on the monitoring results, the present study aims: 1) to confirm that waste material discharged from piggeries is a source of inorganic $\mathrm{N}$ contamination in the surface and groundwater in the commune; 2) to make clear the spatial and temporal variations of ammonium$\mathrm{N}$ and nitrate-N concentrations; and 3) to evaluate the level of ammonium-N and nitrate-N contamination in reference to the water standard.

\section{MATERIALS AND METHODS}

\section{Study area}

Study area is Laivu commune, Kimthanh district, Haiduong province, Vietnam. Laivu commune has three villages of Hopnhat, Minhthanh and Quyettam and the population was 4,954 persons with 1,207 households in 2008. Figure 1 shows location of the three villages in Laivu commune and places of the households who feed pigs. The number of pigs fed in a year by a household is indicated by the size of a circle on the 5 levels.

According to the meteorological data recorded in the Hydrometeorology Centre in Haiduong province 


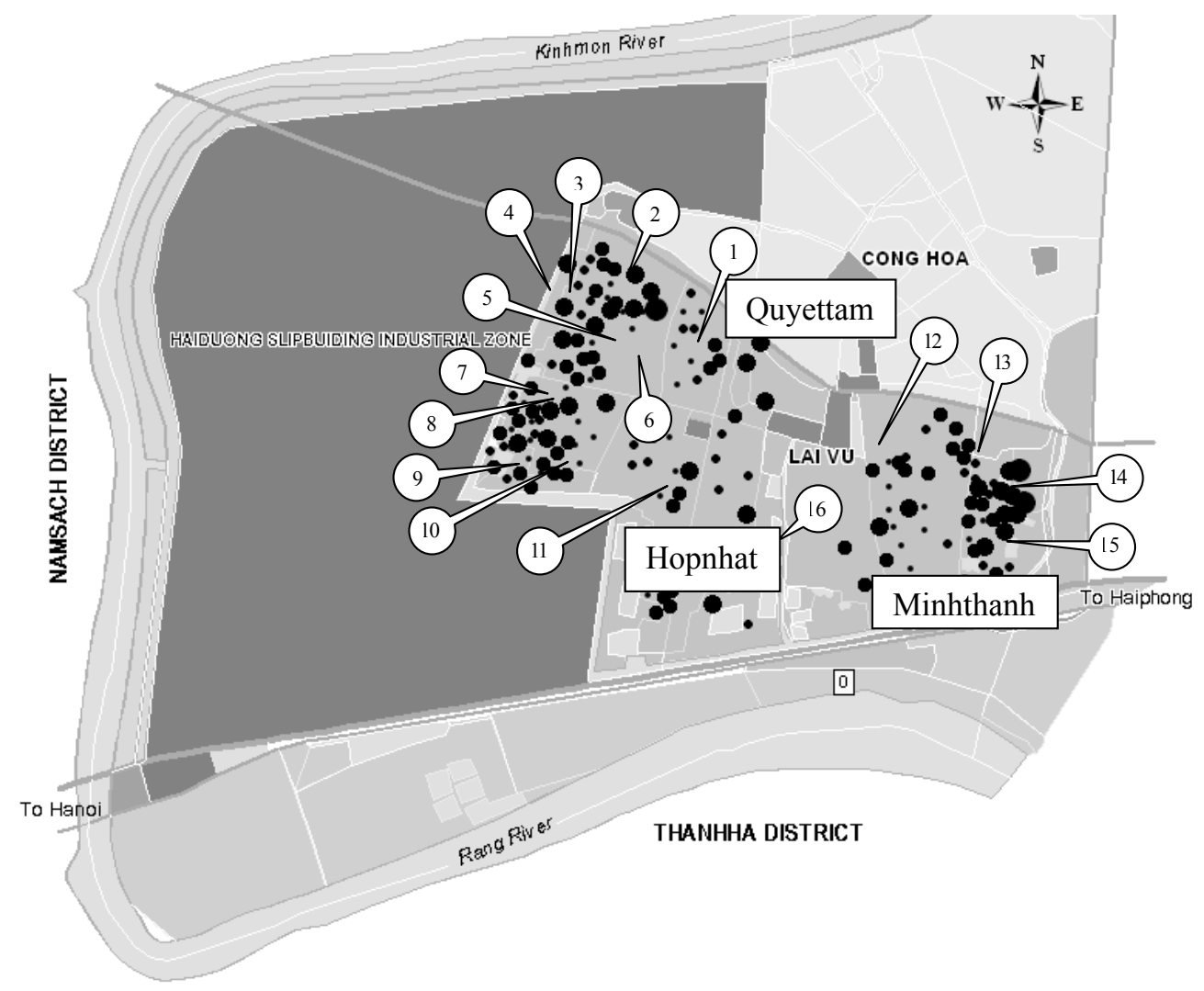

\begin{tabular}{|c|c|c|c|c|c|c|c|}
\hline Village & $\begin{array}{c}\text { Sample } \\
\text { No }\end{array}$ & $\begin{array}{c}\text { Source of } \\
\text { water }\end{array}$ & Village & $\begin{array}{l}\text { Sample } \\
\text { No }\end{array}$ & $\begin{array}{l}\text { Source of } \\
\text { water }\end{array}$ & Symbol & $\begin{array}{l}\text { Number of pigs } \\
\text { in a household }\end{array}$ \\
\hline \multirow{6}{*}{ Quyettam } & 1 & Tubewell & \multirow{3}{*}{ Hopnhat } & 9 & Tubewell & 0 & $101-150$ \\
\hline & 2 & Deep well & & 10 & Tubewell & 0 & $51-100$ \\
\hline & 3 & Tubewell & & 11 & Tubewell & $\bullet$ & $31-50$ \\
\hline & 4 & Ditch & \multirow{4}{*}{ Minhthanh } & 12 & Deep well & $\bullet$ & $21-30$ \\
\hline & 5 & Tubewell & & 13 & Tubewell & $\bullet$ & $10-20$ \\
\hline & 6 & Pond & & 14 & Pond & & \\
\hline \multirow{2}{*}{ Hopnhat } & 7 & Tubewell & & 15 & Tubewell & & \multirow{2}{*}{ Sample number } \\
\hline & 8 & Deep well & Quyettam & 16 & Pond & & \\
\hline
\end{tabular}

Fig. 1. Location of three villages and places of the farming households raising pigs in Laivu commune, Kimthanh district, Haiduong province, Vietnam.

(2007, 2008), annual average rainfall amounted to $1,550 \mathrm{~mm}$. The mean annual air temperature was $23.5^{\circ} \mathrm{C}$, with a monthly average ranging from $13.3^{\circ} \mathrm{C}$ in February to $30.4^{\circ} \mathrm{C}$ in July. The relative humidity was very high throughout the year with an annual mean of $72 \%$.

There are two main groundwater aquifers in the RRD (World Bank, 1995). One aquifer is embedded in Holocene sediments and the other in Pleistocene sediments. The former is water located at a depth of 0.5 to $2 \mathrm{~m}$ from the ground surface during the rainy season and at a depth of 2 to $8 \mathrm{~m}$ during the dry season. Its thickness ranges from a few to $40 \mathrm{~m}$. The latter aquifer is confined and underlies the former with a thickness of 10 to $100 \mathrm{~m}$.

\section{Water sampling}

Water sampling was conducted at three villages of
Hopnhat, Minhthanh and Quyettam in Laivu commune at five times of a two-month interval from August 2007 to April 2008. Sampling sites of surface and groundwater at Hopnhat, Minhthanh and Quyettam villages are shown in Fig. 1, and brief description of the surface and groundwater samples is also given in Fig. 1.

Samples of surface water were collected from pond and/or ditch at one or two sites in each village. Samples of groundwater were collected from tubewell and deep well set at the yard of the farming household at three to five sites in each village. The sampling depth of groundwater was 4 to $12 \mathrm{~m}$. From these depths, the groundwater was thought to belong mostly to the aquifer embedded in Holocene sediments. For comparison, surface and groundwater were sampled in Conghoa commune, next to Laivu commune (Fig. 1), where pig raising at the farming household was not enhanced so rapidly as Laivu commune. 
Five-hundred $\mathrm{mL}$ of water sample was taken from 16 sites in Laivu commune and 4 sites in Conghoa commune. They were brought to the laboratory of the Department of Environmental Technology, Hanoi University of Agriculture, for analysis of ammonium and nitrate ions.

\section{Measurement of concentrations of ammonium and nitrate ions}

Ammonium- and nitrate-ion concentrations were determined by a spectrophotometer (UV/VIS), according to the Nessler method (Greweling and Peech, 1960) and the Cataldo method (Cataldo et al., 1975), respectively. Ammonium-and nitrate-ion concentrations were converted to the concentrations of ammonium-N and nitrate-N, respectively, by applying the molecular weight ratio of $\mathrm{N}$ to $\mathrm{NH}_{4}^{+}$and $\mathrm{NO}_{3}^{-}$. Determination of the concentrations was made in duplicate and the relative deviation of the duplicate values was usually less than $5 \%$.

\section{RESULTS}

\section{Situation of pig raising on the household level in Laivu commune}

Table 1 shows the number and ratio of the household belonging to a specified range in the number of pig fed annually in a household in Quyettam, Hopnhat and Minhthanh villages and in Laivu commune, along with the total number of pig-raising household. According to the data shown in Table 1, pig-raising households were 345 in Laivu commune, occupying $28.6 \%$ of total household, and the number of pig fed in a year per household ranged from 10 to 150 . The household feeding 10 to 20,21 to 30,31 to 50,51 to 100 , and 101 to 150 head of pigs was $43,21,26,9$, and $1 \%$, respectively, of the total pig-raising household.

The above statistics mean that pig raising on the household level is generally in a small to medium scale in Laivu commune. It makes difficult for the construction of storage installation to prevent waste water and solid from discharge from piggeries to the environment. Thus, it is easily imagined that enhancement of pig raising after 2001 just brought about increase in the discharge of waste water and solid from piggeries to ditches and ponds surrounding pig-raising households.

Total number of the pig-raising household and the ratio of the household belonging to a specified range in the number of pig fed annually in a household were recognized to vary with villages (Table 1). Total number of the pig-raising household was highest for Hopnhat (162), followed by Quyettam (126), and lowest for Minhthanh (57). In contrast, the ratio of household belonging to the ranges of 51 to 150 head of pigs per household was highest for Minhthanh (16\%), followed by Quyettam (12\%), and lowest for Hopnhat (7\%). It indicates that concentration and intensification of pig raising on the household level is most advanced for Minhthanh village among the three villages.

Table 1. Number and ratio of the household belonging to a specified range in the number of pig fed annually in a household in Quyettam, Hopnhat and Minhthanh villages and in Laivu commune

\begin{tabular}{|c|c|c|c|c|c|c|c|c|}
\hline \multirow{2}{*}{$\begin{array}{l}\text { Range in the number } \\
\text { of pig fed annually } \\
\text { in a household }\end{array}$} & \multicolumn{2}{|c|}{ Quyettam village } & \multicolumn{2}{|c|}{ Hopnhat village } & \multicolumn{2}{|c|}{ Minhthanh village } & \multicolumn{2}{|c|}{ Laivu commune } \\
\hline & Number & $\begin{array}{c}\text { Ratio } \\
(\%)\end{array}$ & Number & $\begin{array}{c}\text { Ratio } \\
(\%)\end{array}$ & Number & $\begin{array}{c}\text { Ratio } \\
(\%)\end{array}$ & Number & $\begin{array}{c}\text { Ratio } \\
(\%)\end{array}$ \\
\hline $10-20$ & 43 & 34 & 90 & 56 & 15 & 26 & 148 & 43 \\
\hline $21-30$ & 27 & 21 & 33 & 20 & 12 & 21 & 72 & 21 \\
\hline $31-50$ & 41 & 33 & 28 & 17 & 21 & 37 & 90 & 26 \\
\hline $51-100$ & 15 & 12 & 11 & 7 & 7 & 12 & 33 & 9 \\
\hline $101-150$ & 0 & 0 & 0 & 0 & 2 & 4 & 2 & 1 \\
\hline Total & 126 & 100 & 162 & 100 & 57 & 100 & 345 & 100 \\
\hline
\end{tabular}

Table 2. Ammonium-N and nitrate-N concentrations $(\mathrm{mg} / \mathrm{L})$ of the surface water in the 3 villages of Laivu commune at five times of monitoring from August 2007 to April 2008

\begin{tabular}{|c|c|c|c|c|c|c|c|c|}
\hline \multirow[b]{2}{*}{ Inorganic-N } & \multirow[b]{2}{*}{ Village } & \multirow[b]{2}{*}{$\begin{array}{c}\text { Number } \\
\text { of sampling } \\
\text { sites }\end{array}$} & \multicolumn{5}{|c|}{ Monitoring time } & \multirow[b]{2}{*}{$\begin{array}{l}\text { Average of the } \\
\text { whole moni- } \\
\text { toring }\end{array}$} \\
\hline & & & $\begin{array}{c}\text { 1st } \\
\text { Aug } \\
2007\end{array}$ & $\begin{array}{l}\text { 2nd } \\
\text { Oct } \\
2007\end{array}$ & $\begin{array}{l}\text { 3rd } \\
\text { Dec } \\
2007\end{array}$ & $\begin{array}{c}4 \text { th } \\
\text { Feb } \\
2008\end{array}$ & $\begin{array}{c}\text { 5th } \\
\text { Apr } \\
2008\end{array}$ & \\
\hline \multirow{3}{*}{ Ammonium-N } & Quyettam & 2 & 5.08 & 0.87 & 5.21 & 9.48 & 7.17 & 5.56 \\
\hline & Hopnhat & 1 & 0.90 & 1.23 & 3.75 & 3.32 & 4.85 & 2.81 \\
\hline & Minhthanh & 1 & 0.60 & 0.60 & 23.28 & 13.01 & 1.05 & 7.71 \\
\hline \multirow{3}{*}{ Nitrate-N } & Quyettam & 2 & 0.17 & 1.14 & 0.63 & 0.59 & 0.09 & 0.52 \\
\hline & Hopnhat & 1 & 0.19 & 1.55 & 0.13 & 0.35 & 0.49 & 0.54 \\
\hline & Minhthanh & 1 & 0.15 & 2.17 & 0.52 & 0.97 & 1.52 & 1.07 \\
\hline
\end{tabular}


Ammonium- $\mathrm{N}$ and nitrate- $\mathrm{N}$ concentrations in the surface water

Ammonium-N and nitrate- $\mathrm{N}$ concentrations of the surface water in the three villages of Laivu commune at five times of monitoring from August 2007 to April 2008 are shown in Table 2. The concentration for Quyettam village is an average of the concentrations measured at the two sites. Throughout monitoring, the ammonium$\mathrm{N}$ concentration ranged from 0.87 to $9.48 \mathrm{mg} / \mathrm{L}$ for Quyettam, 0.90 to $4.85 \mathrm{mg} / \mathrm{L}$ for Hopnhat, and 0.60 to $23.28 \mathrm{mg} / \mathrm{L}$ for Minhthanh, suggesting that variation with monitoring times was greatest for Minhthanh and least for Hopnhat. The average concentration of ammonium $-\mathrm{N}$ in the whole monitoring was 5.56, 2.81 and $7.71 \mathrm{mg} / \mathrm{L}$ for Quyettam, Hopnhat and Minhthanh, respectively; the value of Minhthanh was higher by 1.39 times than the value of Quyettam and by 2.74 times than the value of Hopnhat. As a result, the maximum and average ammonium- $\mathrm{N}$ concentrations of the surface water in the whole monitoring was highest for Minhthanh, followed by Quyettam, and lowest for Hopnhat. This sequence was well corresponding to the advanced level of the intensification in pig raising on the household level among the three villages (Table 1).

The nitrate- $\mathrm{N}$ concentration of the surface water was generally low irrespective of the villages and ranged form 0.09 to $1.14 \mathrm{mg} / \mathrm{L}$ for Quyettam, 0.13 to $1.55 \mathrm{mg} / \mathrm{L}$ for Hopnhat, and 0.15 to $2.17 \mathrm{mg} / \mathrm{L}$ for Minhthanh, throughout monitoring. The average nitrate- $\mathrm{N}$ concentration of Quyettam, Hopnhat and Minhthanh villages in the whole monitoring was $0.52,0.54$ and $1.07 \mathrm{mg} / \mathrm{L}$, respectively.

\section{Ammonium- $\mathrm{N}$ and nitrate- $\mathrm{N}$ concentrations in the groundwater}

Table 3 shows the maximum, minimum and average concentrations of ammonium- $\mathrm{N}$ and nitrate- $\mathrm{N}$ of the groundwater in the three villages of Laivu commune at five times of monitoring from August 2007 to April 2008. As understood from Table 3, considerable variation of the ammonium-N concentration with sampling sites and with monitoring times were observed in every village, and the maximum and average concentrations of ammonium-N in the whole monitoring were highest for Minhthanh, followed by Quyettam, and lowest for Hopnhat, similar to the ammonium-N concentration of the surface water (Table 2). The average ammonium-N concentration in the whole monitoring was 3.51, 2.65 and $5.50 \mathrm{mg} / \mathrm{L}$ for Quyettam, Hopnhat and Minhthanh, respectively; the value of Minhthanh was higher by 1.57 times than the value of Quyettam and by 2.08 times than the value of Hopnhat. In comparison with that of the surface water (Table 2), the ammonium-N concentration of the groundwater was low for Minhthanh and Quyettam while in a similar level for Hopnhat.

Throughout monitoring of all three villages, the

Table 3. Ammonium-N and nitrate-N concentrations (mg/L) of the groundwater in the 3 villages of Laivu commune at five times of monitoring from August 2007 to Aprill 2008

\begin{tabular}{|c|c|c|c|c|c|c|c|c|}
\hline \multirow[b]{2}{*}{ Inorganic-N } & \multirow[b]{2}{*}{ Village } & \multirow[b]{2}{*}{ Parameter } & \multicolumn{5}{|c|}{ Monitoring time } & \multirow[b]{2}{*}{$\begin{array}{c}\text { Average of the } \\
\text { whole } \\
\text { monitoring }\end{array}$} \\
\hline & & & $\begin{array}{c}\text { 1st } \\
\text { Aug } \\
2007\end{array}$ & $\begin{array}{l}\text { 2nd } \\
\text { Oct } \\
2007\end{array}$ & $\begin{array}{c}3 r d \\
\text { Dec } \\
2007\end{array}$ & $\begin{array}{l}4 \text { th } \\
\text { Feb } \\
2008\end{array}$ & $\begin{array}{l}5 \text { th } \\
\text { Apr } \\
2008\end{array}$ & \\
\hline \multirow{9}{*}{ Ammonium-N } & \multirow{3}{*}{$\begin{array}{l}\text { Quyettam } \\
(\mathrm{n}=4)\end{array}$} & Max & 3.45 & 6.20 & 11.29 & 5.48 & 4.46 & 11.29 \\
\hline & & Min & 0.85 & 0.93 & 3.04 & 0.48 & 1.44 & 0.48 \\
\hline & & Ave & 1.71 & 3.23 & 6.72 & 2.93 & 2.94 & 3.51 \\
\hline & \multirow{3}{*}{$\begin{array}{l}\text { Hopnhat } \\
(n=5)\end{array}$} & Max & 1.75 & 5.81 & 9.01 & 3.44 & 5.22 & 9.01 \\
\hline & & Min & 0.40 & 0.44 & 0.17 & 0.06 & 0.17 & 0.06 \\
\hline & & Ave & 1.31 & 3.20 & 4.41 & 1.61 & 2.74 & 2.65 \\
\hline & \multirow{3}{*}{$\begin{array}{l}\text { Minhthanh } \\
\quad(\mathrm{n}=3)\end{array}$} & Max & 4.20 & 9.92 & 12.89 & 6.34 & 4.79 & 12.89 \\
\hline & & Min & 2.10 & 6.32 & 4.87 & 0.83 & 1.98 & 0.83 \\
\hline & & Ave & 3.07 & 8.21 & 9.05 & 3.79 & 3.36 & 5.50 \\
\hline \multirow{9}{*}{ Nitrate-N } & \multirow{3}{*}{$\begin{array}{l}\text { Quyettam } \\
\quad(\mathrm{n}=4)\end{array}$} & $\operatorname{Max}$ & 0.23 & 0.80 & 0.62 & 0.24 & 1.78 & 1.78 \\
\hline & & Min & 0.07 & 0.23 & 0.33 & 0.04 & 0.06 & 0.04 \\
\hline & & Ave & 0.13 & 0.52 & 0.49 & 0.11 & 0.78 & 0.41 \\
\hline & \multirow{3}{*}{$\begin{array}{l}\text { Hopnhat } \\
(\mathrm{n}=5)\end{array}$} & Max & 2.75 & 0.85 & 0.73 & 1.65 & 0.52 & 2.75 \\
\hline & & Min & 0.07 & 0.27 & 0.44 & 0.04 & 0.16 & 0.04 \\
\hline & & Ave & 0.63 & 0.53 & 0.58 & 0.52 & 0.32 & 0.52 \\
\hline & \multirow{3}{*}{$\begin{array}{l}\text { Minhthanh } \\
\quad(\mathrm{n}=3)\end{array}$} & $\operatorname{Max}$ & 1.14 & 1.09 & 0.83 & 0.96 & 0.87 & 1.14 \\
\hline & & Min & 0.08 & 0.32 & 0.18 & 0.07 & 0.17 & 0.07 \\
\hline & & Ave & 0.44 & 0.63 & 0.53 & 0.65 & 0.43 & 0.54 \\
\hline
\end{tabular}

$\mathrm{n}$ : number of sampling sites. 
nitrate-N concentration ranged from 0.04 to $2.75 \mathrm{mg} / \mathrm{L}$. The average nitrate- $\mathrm{N}$ concentration in the whole monitoring was $0.41,0.52$ and $0.54 \mathrm{mg} / \mathrm{L}$ for Quyettam, Hopnhat and Minhthanh, respectively, and was not much different with one another among the three villages and was considerably lower than the corresponding values of ammonium-N.

\section{DISCUSSION}

\section{Source of inorganic- $\mathbf{N}$ in the surface and ground- water}

Estimation of $N$ discharged from piggeries in Laivu commune

According to the Department of Science and Technology, Haiduong province, the normal weight of waste solid excreted by a head of pig for one day and night was estimated to be $0.8 \mathrm{~kg}$ in average. Around 7,665 to 13,120 head of pigs are fed in total 345 pig-raising households in Laivu commune. Those figures suggest that waste solid roughly equivalent to 6,100 to 10 , $500 \mathrm{~kg}$ is discharged daily from piggeries on the commune level. The $\mathrm{N}$ content of pig waste solid was reported to be $5 \%$ by Burton and Turner (1998). Multiplication of the amount of 6,100 to $10,500 \mathrm{~kg}$ by the $\mathrm{N}$ content of $5 \%$ gives 310 to $520 \mathrm{~kg}$ of $\mathrm{N}$ which is daily discharged as waste solid from piggeries in Laivu commune. The $\mathrm{N}$ concentration of pig waste water has been determined as 1,500 to 15,200 mg-N/L (Eun and Choi, 2002; Choi and Hong, 2002).

The above calculation and quotation indicate that a fairly considerable quantity of $\mathrm{N}$ has been discharged as waste water or solid from piggeries to water body such as pond and ditch in the commune. Waste water and solid is discharged directly without any treatment and can be considered as a source of inorganic-N detected in the surface and groundwater in the water monitoring of Laivu commune. It probably influences adversely the surface and groundwater quality and promotes eutrophication or deterioration of water body.

Comparison of ammonium-N and nitrate- $N$ concentrations of the surface and groundwater between

\section{7-2008 and 2001 in Laivu commune}

To evaluate waste water and solid discharged from piggeries as a source of $\mathrm{N}$ in the surface and groundwater in Laivu commune more directly, ammonium-N and nitrate-N concentrations of the surface and groundwater measured at the present monitoring (2007-2008) were compared with those measured in 2001 when pig raising was on a low level before expropriation of cultivated land from farmers. The comparison is shown in Fig. 2.

According to the data kept in the Environmental Technology Center, the average ammonium-N and nitrate-N concentrations of the surface water in 2001 were 0.50 and $0.32 \mathrm{mg} / \mathrm{L}$, respectively. As calculated from data in Table 2, the average ammonium-N and nitrate-N concentrations of the surface water in 20072008 were 5.36 and $0.71 \mathrm{mg} / \mathrm{L}$, respectively. The average ammonium-N and nitrate-N concentrations in the surface water of Laivu commune were higher by 10.7 and 2.2 times, respectively, for 2007-2008 than for 2001.

In case of the groundwater, the average ammonium-N and nitrate- $\mathrm{N}$ concentrations were 0.39 and $0.24 \mathrm{mg} / \mathrm{L}$, respectively, for 2001 and 3.89 and $0.49 \mathrm{mg} / \mathrm{L}$, respectively, for 2007-2008. The average ammonium-N and nitrate-N concentrations of the groundwater increased by 10.0 and 2.0 times, respectively, between 2001 and 2007-2008.

The above comparison manifests that the inorganic$\mathrm{N}$ concentration of the surface and groundwater was increased since 2001 in Laivu commune and that its increase is connected with enhancement of pig raising due to shift of the fundamental agricultural production system from rice cultivation to pig raising. The temporal concentration increase was more conspicuous for ammonium-N in both surface and groundwater.

Comparison of ammonium-N and nitrate-N concentrations of the surface and groundwater between Laivu and Conghoa communes in 2007-2008

In addition to the comparison between 2007-2008 and 2001 in Laivu commune, ammonium-N and nitrate$\mathrm{N}$ concentrations of the surface and groundwater measured in Laivu commune were compared with those measured in Conghoa commune in the present monitor-
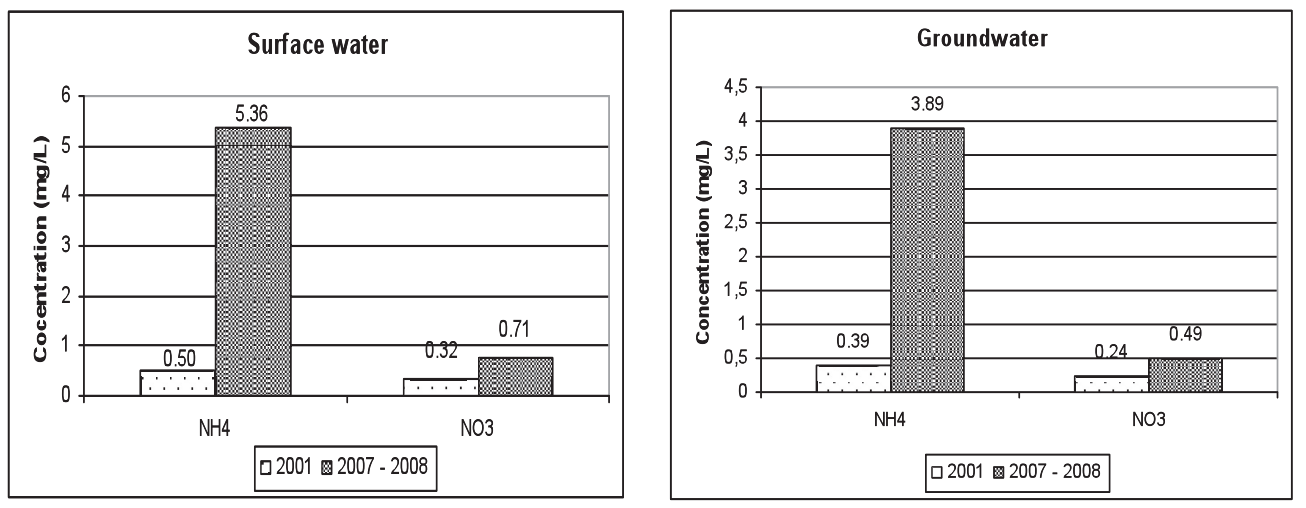

Fig. 2. Comparison of the average ammonium-N and nitrate-N concentrations of the surface and groundwater between 2007-2008 and 2001 in Laivu commune. 

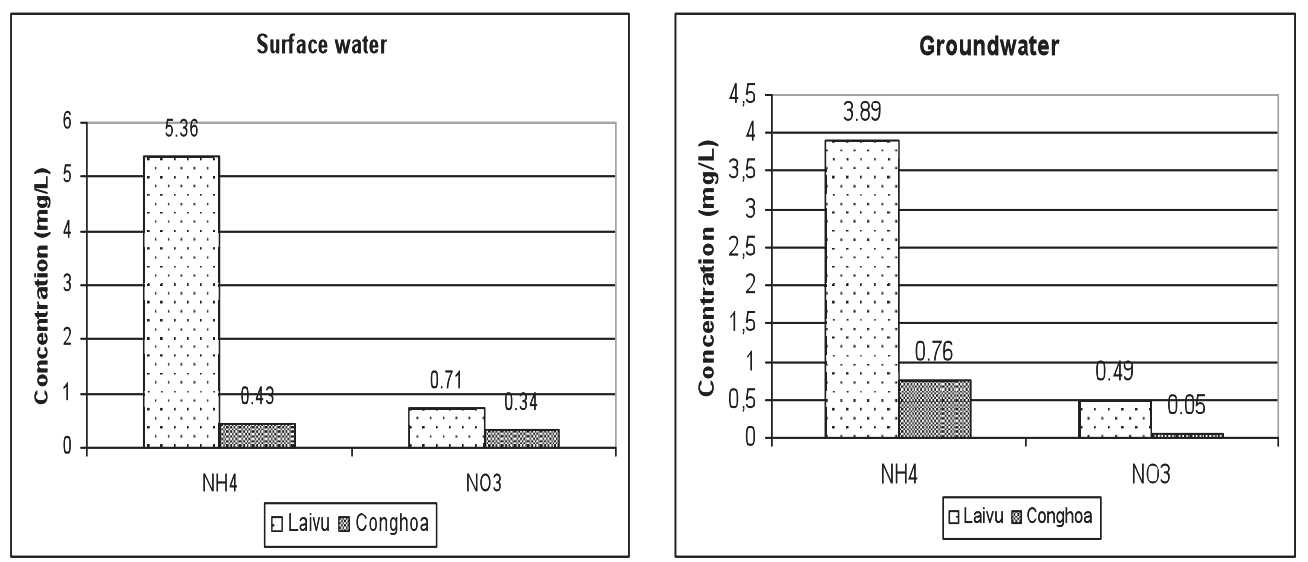

Fig. 3. Comparison of the average ammonium-N and nitrate-N concentrations of the surface and groundwater between Laivu and Conghoa communes in 2007-2008.

ing. As shown in Fig. 3, the average ammonium-N and nitrate-N concentrations of the surface water were 5.36 and $0.71 \mathrm{mg} / \mathrm{L}$, respectively, for Laivu commune, while 0.43 and $0.34 \mathrm{mg} / \mathrm{L}$, respectively, for Conghoa commune. The average ammonium- $\mathrm{N}$ and nitrate- $\mathrm{N}$ concentrations of the groundwater were 3.89 and $0.49 \mathrm{mg} / \mathrm{L}$, respectively, for Laivu commune while 0.76 and $0.05 \mathrm{mg} / \mathrm{L}$, respectively, for Conghoa commune. As a result, the average ammonium-N and nitrate-N concentrations of Laivu commune were higher by 12.5 and 2.1 times, respectively, for surface water and by 5.1 and 9.8 times, respectively, for groundwater than the average concentrations of Conghoa commune, which were on a comparable level to the average concentrations of Laivu commune in 2001.

Three approaches described in the above clarified that ammonium-N and nitrate-N concentrations in both surface and groundwater were remarkably increased in Laivu commune due to enhancement of pig raising since 2001. It can be stated that waste water and solid discharged directly from piggeries are a source of inorganic-N contaminating surface and groundwater in
Laivu commune.

Temporal and spatial variations of the ammonium$\mathbf{N}$ concentration in the surface and groundwater and the future prospect

\section{Temporal variation}

As shown in Fig. 4, the average ammonium-N concentration in the surface and groundwater did not increase or decrease steadily with the monitoring time in three villages of Laivu commune. Instead, the wavy temporal variation was noticed with maximum at the 3rd (December 2007) and 4th (February 2008) monitoring times for the surface water and at the 2nd (October 2007) and 3rd (December 2007) monitoring times for the groundwater. Nitrogen is discharged as an organic form into ditches flowing around piggeries and ponds in villages. Organic $\mathrm{N}$ is relatively quickly decomposed by microorganisms to ammonium ion. Ammonium ion once formed in surface water is then absorbed by aquatic plants and decreases with time. Growth of aquatic plants may be slow in the winter season, leading to remaining of ammonium ion in surface water with the maximum ammonium-N concentration at the 3rd (December 2007) and 4th (February 2008)
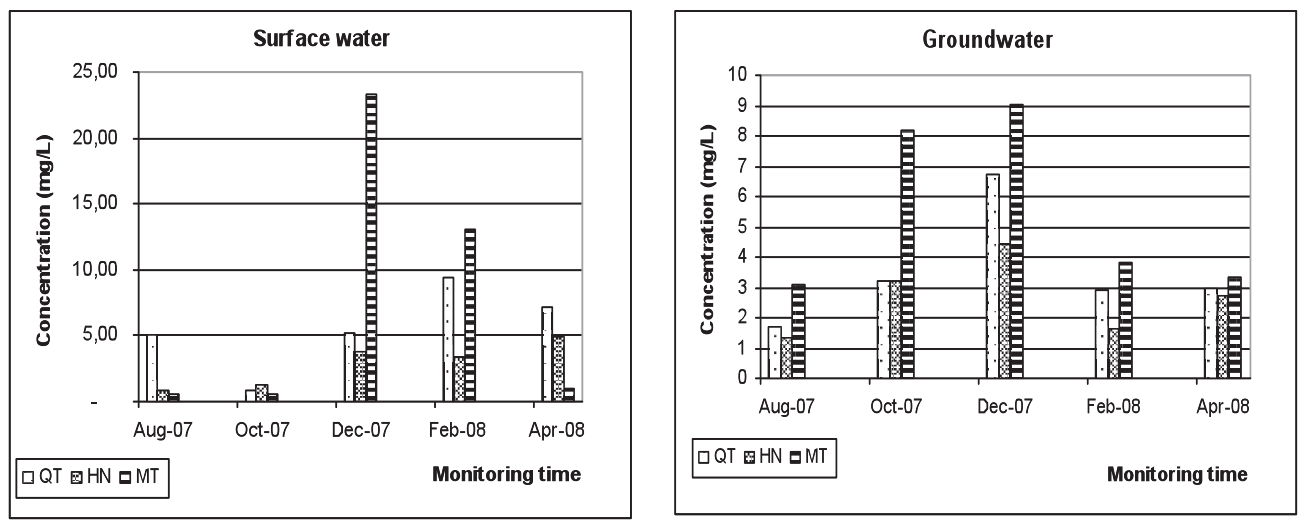

Fig. 4. Temporal variations in the average ammonium-N concentration of the surface and groundwater in Quyettam, Hopnhat and Minhthanh villages of Laivu commune. QT: Quyettam; HN: Hopnhat; MT: Minhthanh. 
monitoring times. Evaporation or denitrification may have some contribution to loss of ammonium ion from surface water.

A wavy variation of the ammonium-N concentration indicates no steady increase of ammonium-N in surface water under the present situation. However, enhancement of pig raising to the more advanced level than the present level without any improvement in the treatment of discharged materials brings about release of a massive amount of waste water and solid to surface water body. Under the situation that discharge of organic $\mathrm{N}$ and subsequent decomposition to ammonium ion always exceeds loss of it due to uptake by aquatic plants and evaporation or denitrification, steady increase of ammonium-N in surface water is expected.

A wavy variation of the ammonium-N concentration was also observed to the groundwater in three villages of Laivu commune. Ammonium ion in groundwater comes from its downward movement from surface water with percolating water. Downward movement of ammonium ion from surface to groundwater means steady or stepwise increase of ammonium-N in groundwater. Even if the movement is discontinuous, reflecting a wavy variation of the ammonium-N concentration in the surface water, it does not lead to a wavy variation of the ammonium-N concentration in the groundwater, because uptake of ammonium-N by aquatic plants is unlikely and little nitrifying and denitrifying activities of microorganisms are supposed in groundwater.

A wavy variation of the ammonium-N concentration presently observed in the groundwater is difficult to be understood, but it is most conceivable that the wavy variation of the ammonium-N concentration is caused by dilution with recharge of groundwater. It has been reported that natural groundwater recharge, equivalent to $280 \mathrm{~mm}$ in depth, into the aquifer of Holocene sediments occurs annually in the RRD (World Bank, 1995). No steady increase in the ammonium-N concentration of the groundwater recognized in the present study is expected to continue in future under the present situation of pig raising in Laivu commune.

Spatial variation

Spatial variation, the difference in the ammonium$\mathrm{N}$ concentration among the three villages, was observed in both surface and groundwater. The average ammonium-N concentration of the surface and groundwater in the whole monitoring was highest for Minhthanh, followed by Quyettam, and lowest for Hopnhat. This sequence was related positively to the ratio of the household feeding 51 to 150 head of pigs to the total pig raising household in a village and negatively to the number of pig-raising household in a village. It is considered that the averaged level of ammonium-N in the surface and groundwater is controlled by advancement in the intensification and concentration of pig raising on the village level.

\section{Comparison with the water standards}

Comparison with the Vietnamese water quality standard for domestic water supply (TCVN:5502/2003)
The Vietnamese water quality standard for domestic water supply is equal to or less than $3 \mathrm{mg} / \mathrm{L}$ for ammonium-N and equal to or less than $10 \mathrm{mg} / \mathrm{L}$ for nitrate-N. The ammonium-N concentration in the surface (Table 2) and groundwater (Table 3) in Quyettam and Minhthanh villages mostly exceeded the standard. The average ammonium-N concentrations of 5.56 and $7.71 \mathrm{mg} / \mathrm{L}$ in the surface water for Quyettam and Minhthanh villages, respectively, were greater by 1.85 and 2.57 times, respectively, than the standard. The average ammonium-N concentrations of 3.51 and 5.50 in the groundwater for Quyettam and Minhthanh villages, respectively, were greater by 1.17 and 1.83 times, respectively, than the standard. Only the average ammonium-N concentrations in the surface $(2.81 \mathrm{mg} / \mathrm{L})$ and groundwater $(2.65 \mathrm{mg} / \mathrm{L})$ of Hopnhat village were somewhat lower than the standard.

Concerning the nitrate-N concentration in the surface and groundwater in three villages of Laivu commune, even the maximum concentrations of $2.17 \mathrm{mg} / \mathrm{L}$ in the surface water and of $2.75 \mathrm{mg} / \mathrm{L}$ in the groundwater well satisfied the Vietnamese water quality standard for domestic water supply.

Comparison with the National technical regulation on surface and underground water quality for running water

The standard of the National technical regulation on surface and underground water quality for running water is equal to or less than $0.01 \mathrm{mg} / \mathrm{L}$ for ammonium$\mathrm{N}$ and equal to or less than $2 \mathrm{mg} / \mathrm{L}$ for nitrate-N. All ammonium-N concentrations in the surface (Table 2) and groundwater (Table 3) in the present monitoring exceeded the standard. The average ammonium-N concentrations of $5.56,2.81$ and $7.71 \mathrm{mg} / \mathrm{L}$ in the surface water for Quyettam, Hopnhat and Minhthanh villages, respectively, were greater by 556, 281 and 771 times, respectively, than this standard. Even the minimum ammonium-N concentrations of $0.60 \mathrm{mg} / \mathrm{L}$ in the surface water and of $0.06 \mathrm{mg} / \mathrm{L}$ in the groundwater exceeded by 15.4 and 1.54 times, respectively, the standard. The National technical regulation on surface and underground water quality for running water may be too strict as the water standard on ammonium-N.

Contrary to the ammonium-N concentration, the nitrate- $\mathrm{N}$ concentration of the surface and groundwater in the present monitoring in Laivu commune was always lower than the standard of the National technical regulation on surface and underground water quality for running water. Even the maximum nitrate-N concentrations of $2.17 \mathrm{mg} / \mathrm{L}$ in the surface water and of $2.75 \mathrm{mg} / \mathrm{L}$ in the groundwater satisfied the standard. It is not necessary to pay much attention to nitrate-N at present.

\section{Alarming situation}

Surface and groundwater is in a critical condition in three villages of Laivu commune in terms of the high ammonium-N concentration. Ditches surrounding piggeries are so dirty in appearance and dark in color. The average ammonium-N concentration of groundwater even exceeded $0.78 \mathrm{mg} / \mathrm{L}$ in every village, above which 
human internal organ systems may be damaged from long-term ingestion (Oregon Department of Human Services, 2000). Now, use of surface and groundwater for drinking and cooking purposes is prohibited in Laivu commune, and clean water is distributed to village people by the local government. Special attention should be paid to the alarmingly high level of ammonium-N in the surface and groundwater in the intensively livestock-raising as well as farming villages of the RRD.

\section{CONCLUSIONS}

Pig raising has been enhanced to the present level since 2001 in Laivu commune, Kimthanh district, Haiduong province in northern Vietnam. The pig-raising household feeding 10 to 150 pigs annually per household occupies $28.6 \%$ of the total household in the commune. Pig waste water and solid were identified as a source of $\mathrm{N}$ contaminating surface and groundwater. The ammonium-N concentration was considerably higher than the nitrate-N concentration and showed a wavy temporal variation in both surface and groundwater. The tendency of no steady increase with time was expected to continue in future under the present level of pig raising. Spatial variation of the ammonium-N concentration in the surface and groundwater was ascribed to the difference in the intensification of pig-raising among the three villages in Laivu commune. The ammonium-N concentration in the surface and groundwater exceeded the Vietnamese water quality standard for domestic water supply and far exceeded the standard of the National technical regulation on surface and underground water quality for running water, whereas the nitrate-N concentration was below the both standards. Attention should be paid to the alarmingly high level of ammonium-N in the surface and groundwater in the intensively livestock-raising as well as farming villages of the Red River Delta.

\section{REFERENCES}

Burton, C. H. and C. Turner 1998 Manure Management. Treatment strategies for sustainable agriculture (2nd ed.). Wrest Park, UK

Cataldo, D. A., M. Haroon, L. E. Schrader and V. L. Youngs 1975 Rapid colorimetric determination of nitrate in plant tissue by nitration of salicylic acid. Communications in Soil
Science and Plant Analysis. 6: 71-80

Chiemchaisri, C., C. Panchawaranon, S. Rutchatanunti, A. Kludpiban, H. H. Ngo and S. Vigeswaran 2003 Development of floating plastic media filtration system for water treatment and wastewater reuse. Journal of Environmental Science and Health Part A 38(10): 2359-2368

Choi, Y. S. and S. W. Hong 2002 Development of biological process for live stock wastewater treatment using a technique for predominant outgrowth of Bacillius species. Wat. Sci. Technol. 45 (12): 71-78

Environmental Technology Centre - ENTEC 2005 Report of environment impact assessment for Haiduong shipbuilding industrial zone building. pp. 37-39

Eun, Y. and E. Choi 2002 Optimization of nitrogen removal from piggery waste by nitrite nitrification. Wat. Sci. Technol. 45(12): 89-96

Greweling, T. and M. Peech 1960 Chemical Soil Tests. Cornell Univ. Agr. Exp. Sta. Bull.

Heaton, T. H. E 1986 Isotopic studies of nitrogen pollution in the hydrosphere and atmosphere: a review. Chemical Geology 59: $87-102$

Hydrometeorological Centre in Haiduong Province 2007 Hydrometeorological data of Haiduong province, Vietnam (in Vietnamese)

Hydrometeorological Centre in Haiduong Province 2008 Hydrometeorological data of Haiduong province, Vietnam (in Vietnamese)

Kurosawa, K., N. H. Do, H. T. Nguyen, T. L. T. Ho, T. L. H. Tran, T. C. Nguyen and K. Egashira 2006 Temporal and spatial variations of inorganic nitrogen levels in surface and ground water around Ha Noi, Viet Nam. Communications in Soil Science and Plant Analysis 37: 403-415

Kurosawa, K., N. H. Do, H. T. Nguyen, T. L. T. Ho, T. L. H. Tran, Q. H. Trinh and K. Egashira 2008 Excessive levels of inorganic nitrogen in groundwater in farmed areas of northern Vietnam. Communications in Soil Science and Plant Analysis 39: 2053-2067

Ministry of National Resources and Environment QCVN 08:2008/ BTNMT 2008 National technical regulation on surface water quality. Ministry of National Resources and Environment: Hanoi, 2008 (in Vietnamese)

Ministry of National Resources and Environment QCVN 09:2008/ BTNMT 2008 National technical regulation on underground water quality. Ministry of National Resources and Environment, Hanoi (In Vietnamese)

Oregon Department of Human Services 2000 Health Effects Information Ammonia. Technical Bulletin; Oregon Health Division, Department of Human Services, Portland, OR, pp. $2-4$

World Bank 1995 Red River Delta Master Plan Vol 2. The Present Situation. Ministry of Science, Technology and Environment, Hanoi

World Bank 2003 Vietnam Environment Monitor 2003 Water. World Bank, Danish International Development Assistance and Ministry of Natural Resources and Environment, Hanoi 